Original article

\title{
The effects of progesterone priming on reproductive performance of GnRH-PGF $2 \alpha$-treated anestrous goats
}

\author{
Mustafa Q. HuSEIN ${ }^{\mathrm{a}}$, Mohammed M. ABABNEH ${ }^{\mathrm{b}}$, Serhan G. HADDAD ${ }^{\mathrm{a}}$ \\ a Department of Animal Production, Faculty of Agriculture, PO Box 3030, \\ Jordan University of Science and Technology, Irbid 22110, Jordan \\ b Department of Veterinary Clinical Sciences, Faculty of Veterinary Medicine, PO Box 3030, \\ Jordan University of Science and Technology, Irbid 22110, Jordan
}

(Received 9 February 2005; accepted 29 April 2005)

\begin{abstract}
The objective of this experiment was to determine the effect of a 5-day progesterone priming prior to a GnRH-PGF $2 \alpha$ treatment on reproductive performance of anestrous goats. Thirtysix Mountain Black goats were randomly assigned in a $2 \times 2$ factorial arrangement and were administered intravaginally on day -12 , either with $300 \mathrm{mg}$ progesterone inserts (CGPE and CGP) or with $0 \mathrm{mg}$ progesterone (GPE and GP) for 5 days. On day -6 , the goats were injected with $100 \mu \mathrm{g}$ $\mathrm{GnRH}$, followed 6 days later by $15 \mathrm{mg} \mathrm{PGF}_{2 \alpha}$ (day 0), the time at which the goats in the CGPE and GPE groups were administered $300 \mathrm{IU}$ eCG injections and those in CGP and GP groups were administered the control solution. The goats were exposed to four fertile bucks at $0 \mathrm{~h}$ and were checked for breeding marks at 6-h intervals for $72 \mathrm{~h}$. Blood samples were collected from all goats for progesterone analysis. Progesterone concentrations increased only in CGPE and CGP during the period of device insertion but remained low in GPE and GP groups $(P<0.001)$. Progesterone levels at the time of $\mathrm{GnRH}$ injection on day -6 were basal $\left(0.2 \pm 0.04 \mathrm{ng} \cdot \mathrm{mL}^{-1}\right)$ among the groups and began to increase starting on day -2 . Day 0 progesterone concentrations differed $(P<0.05)$ among groups and were significantly influenced by CIDR-G $(P<0.001)$. A similar proportion of goats expressed estrus and intervals to detected estrus were shorter $(P<0.05)$ in the CGPE and GPE groups than in GP with no difference between the CGPE, CGP and GPE or between CGP and GP groups. The number of goats ovulating based upon elevated progesterone levels on day 0 was significantly greater $(P=0.002)$ in CGPE $(9 / 9)$ and CGP (9/9) than GPE (6/9) and GP (5/9) groups and was significantly influenced by CIDR-G $(P=0.03)$. All pregnant goats had elevated progesterone concentration on day 0 and none of the goats with basal progesterone levels became pregnant. Pregnancy and kidding rates, twinning percentage and the number of kids born per goat exposed were greater $(P<0.05)$ among goats treated with progesterone and eCG. In conclusion, progesterone priming and eCG are essential for producing higher rates of pregnancy and kidding in GnRH-PGF $2 \alpha^{-}$ treated anestrous goats.
\end{abstract}

estrus synchronization / progesterone priming / GnRH / $\mathbf{P G F}_{2 \alpha} /$ goats

* Corresponding author: huseinmq@just.edu.jo 


\section{INTRODUCTION}

A successful goat enterprise is closely related to the level of kid production. Hormonal treatment for estrus synchronization or induction is effective in increasing the proportion of females that become pregnant. A number of strategies have been used to stimulate and control ovarian activity in goats with the aim of increasing fertility rates. Progesterone-containing inserts combined with eCG at the time of insert withdrawal, is perhaps the most widely used technique $[1,2]$. However, low first-cycle conception rate and poor fertility has accompanied progestagen usage in some cases [3-6] and thus, efforts are being made for alternatives. The potential use of $\mathrm{GnRH}-$ $\mathrm{PGF}_{2 \alpha}$ has been reported in cattle [7, 8]. The alteration of ovarian follicular dynamics with GnRH prior to induction of corpus luteum regression with $\mathrm{PGF}_{2 \alpha}$, improves the precision of estrus response $[9,10]$. In sheep, a 4-day progesterone priming was essential for the effectiveness of the GnRH$\mathrm{PGF}_{2 \alpha}$ protocol in anestrous ewes [11]. Progesterone priming prevented follicular turnover and maintained large follicles responsive to GnRH and sensitized GnRH$\mathrm{PGF}_{2 \alpha}$-treated anestrous ewes [11]. The use of GnRH-PGF $2 \alpha$ in progesterone-pretreated goats has not yet been documented. The objective of this experiment was to determine the effect of a 5-day progesterone priming prior to a $\mathrm{GnRH}-\mathrm{PGF}_{2 \alpha}$ treatment with or without eCG on the reproductive performance of anestrous goats.

\section{MATERIALS AND METHODS}

\subsection{Animals}

Thirty-six pluriparous anestrous Mountain Black goats, weighing $39.2 \pm 0.5 \mathrm{~kg}$, were studied in an experiment conducted at the Agricultural Center for Research and Production at the Jordan University of Science and Technology located in the northwestern part of Jordan at $32^{\circ} 33^{\prime} \mathrm{N} 35^{\circ} 51^{\prime} \mathrm{E}$ and an altitude of $850 \mathrm{~m}$ during the months of May and June 2003. All goats had previously kidded at least once with an average litter size of 1.1 kids per doe kidding and 0.9 kid per doe exposed. The goat's last kidding dates ranged from November 15, 2002 to February 1, 2003, and had their kids weaned by May 5, 2003. The goats were fed $1 \mathrm{~kg}$ alfalfa hay and $0.5 \mathrm{~kg}$ concentrate mixture per goat per day. Trace mineral salt blocks and water were available ad libitum.

\subsection{Experimental design}

GnRH-PGF $2 \alpha$-treated anestrus goats $(n=36)$ were randomly assigned in equal numbers in a $2 \times 2$ factorial arrangement and were administered intravaginally on May 17 (day -12) with either 300 mg progesterone (CIDR-G, Pharmacia and Upjohn Limited Company, MT Wellington, Auckland) inserts (CGPE and CGP) or $0 \mathrm{mg}$ progesterone (GPE and GP). The inserts were kept in place for 5 days and were removed on May 22 (day-7). Twenty-four hours following insert removal (May 23), the goats were injected i.m. with $100 \mu \mathrm{g} \mathrm{GnRH}$ (Cystorelin, Sanofi Animal Health, Libourne Cedex, France), followed 6 days later by $15 \mathrm{mg} \mathrm{PGF} 2 \alpha$ injection (Lutalyse, Pharmacia \& Upjohn n.v./s.a. Puurs, Belgium). Immediately following the $\mathrm{PGF}_{2 \alpha}$ injection on May 29 (day 0), each goat in the CGPE and GPE groups was administered i.m. with 300 IU eCG injection (Sanofi Animal Health, Libourne Cedex, France) and those in the CGP and GP groups were administered with saline. All goats were run together in a single pen with four fertile bucks whose briskets were painted with white paint. The bucks were turned-in with the goats immediately following the $\mathrm{PGF}_{2 \alpha}$ injection and the goats were checked for breeding marks at 6-h intervals for $72 \mathrm{~h}$.

\subsection{Blood sampling and hormone assay}

Blood samples were collected via jugular venipuncture from all goats once daily 
starting immediately before CIDR-G insertion on day -12 until day 0 to verify progesterone concentrations during the period of progesterone priming among the groups. Blood samples were also collected once daily from day 0 until day 5 and every three days thereafter until day 23 to measure progesterone concentrations and determine pregnancy. Blood samples (5 mL each) were drawn into heparinized tubes (5 IU heparin $\cdot \mathrm{mL}^{-1}$ blood) and centrifuged soon after collection. Plasma was pipetted and stored at $-20{ }^{\circ} \mathrm{C}$ until it was assayed using radioimmunoassay (Progesterone Coat-ACount Kit, Diagnostic Products Corporation, DPC, Los Angeles, CA). Sensitivity was $0.1 \mathrm{ng} \cdot \mathrm{mL}^{-1}$ and the intra-assay coefficient of variation was $5.2 \%$.

\subsection{Statistical analysis}

Data were analyzed using SAS/STAT ANOVA procedures (1996). Means \pm SEM are presented in the text, tables and figures. The effects of progesterone (CIDR-G) priming prior to $\mathrm{GnRH}-\mathrm{PGF}_{2 \alpha}$ treatment and $\mathrm{eCG}$ on the incidence of estrus, firstcycle pregnancy and kidding rates were analyzed by the categorical model (CATMOD) to determine the effects of CIDR-G and eCG treatments and their interactions. When significant effects were found, data were compared between treatment groups by the Chi-square test. The effects of the CIDR-G pretreatment and eCG at $0 \mathrm{~h}$ on various intervals were tested using the least-squares mean of the GLM procedures. Progesterone concentrations were analyzed for the effect of progesterone priming and time using the repeated-measures procedure of GLM. The ovulation or luteinization following $\mathrm{GnRH}$ treatment was considered to have occurred based upon progesterone levels of $0.4 \mathrm{ng} \cdot \mathrm{mL}^{-1}$ or greater on day 0 . The first-cycle pregnancy rate was defined as the number of goats bred by bucks within $72 \mathrm{~h}$ following day 0 and became pregnant based upon sustained progesterone levels of $\geq 3 \mathrm{ng} \cdot \mathrm{mL}^{-1}$ between days 17 and 23 following day 0 . Pregnancy was confirmed on day 35 using a $5-\mathrm{MHz}$ ultrasound transducer (485 Anser Vet, Pie Medical Equipment B.V., Philipsweg, AJ Maastricht, The Netherlands).

\section{RESULTS}

\subsection{Progesterone concentrations from day -12 until day 0}

No CIDR-G inserts were lost during the period of insertion. Plasma progesterone profiles among goats of the four groups from day -12 until day 0 are illustrated in Figure 1. Initial (day -12) progesterone concentrations were less than $0.3 \pm$ $0.2 \mathrm{ng} \cdot \mathrm{mL}^{-1}$ among the goats of four groups. During the period of progesterone priming, plasma concentrations increased rapidly and reached maximum values of $4.9 \pm$ 0.5 and $4.8 \pm 0.4 \mathrm{ng} \cdot \mathrm{mL}^{-1} 2$ days post CIDR$\mathrm{G}$ insertion in CGPE and CGP groups, respectively, but remained below $0.3 \mathrm{ng} \cdot \mathrm{mL}^{-1}$ in GPE and GP groups. Progesterone in CGPE and CGP groups decreased gradually by day $(P<0.01)$ during the remaining 3 days to $2.8 \pm 0.1$ and $2.6 \pm 0.1 \mathrm{ng} \cdot \mathrm{mL}^{-1}$, respectively and were significantly different $(P<0.001)$ from those $\left(0.3 \pm 0.2 \mathrm{ng} \cdot \mathrm{mL}^{-1}\right)$ of GPE and GP groups. Progesterone concentrations between days -10 and -7 were higher $(P<0.001)$ in CGPE and CGP than in GPE and GP groups, reflecting an exogenous treatment. On day -6 , at the time of GnRH injection, which was given one day following CIDR-G removal, plasma concentrations were below $0.2 \pm 0.04 \mathrm{ng} \cdot \mathrm{mL}^{-1}$ and were similar among groups. The $\mathrm{GnRH}$ treatment was given when all goats had basal progesterone concentrations, which began to increase starting on day -2 . On day 0 , at the time of the $\mathrm{PGF}_{2 \alpha}$ injection, progesterone concentrations were elevated and averaged $1.8 \pm 0.2,1.2 \pm 0.3,0.7 \pm 0.2$ and $0.8 \pm 0.2 \mathrm{ng} \cdot \mathrm{mL}^{-1}$ for groups CGPE, CGP, GPE and GP, respectively. Progesterone concentrations on day 0 differed $(P<0.05)$ among groups and were significantly influenced by CIDR-G $(P<0.001)$ but not by 


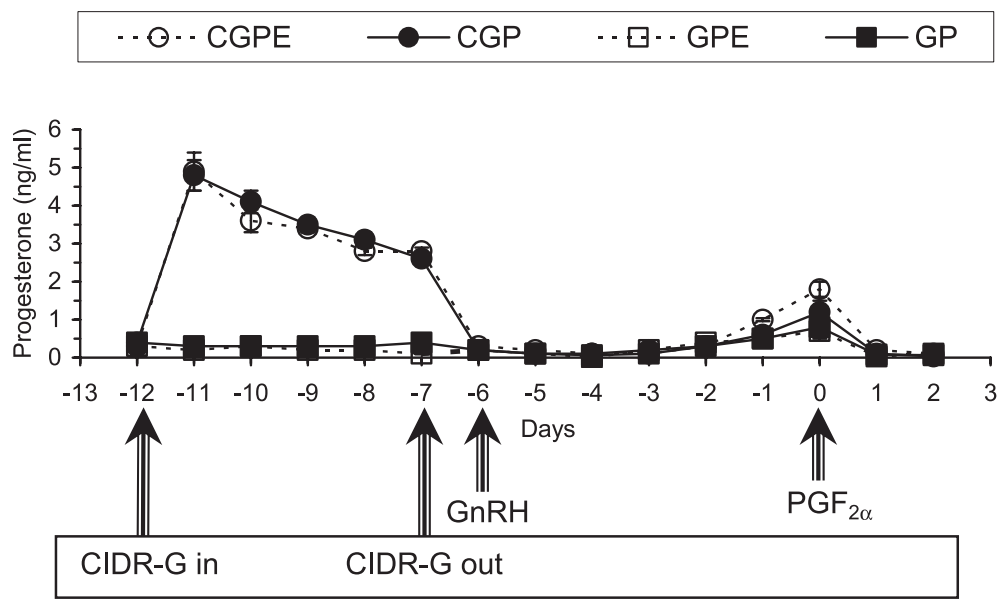

Figure 1. Plasma progesterone concentrations from day -12 until day 0 in $\mathrm{GnRH}-\mathrm{PGF}_{2 \alpha}$-treated anestrous goats.

eCG or the interaction between CIDR-G and eCG (Fig. 1). The number of goats with elevated progesterone levels on day 0 was significantly greater $(P=0.002)$ in CGPE $(9 / 9)$ and CGP (9/9) than GPE (6/9) and GP $(5 / 9)$ groups and was significantly influenced by CIDR-G $(P=0.03)$ but not by eCG or the interaction between CIDR-G and eCG.

\subsection{Reproductive performance following day 0}

Reproductive performance following day 0 among the goats of the four groups is presented in Table I. Neither treatment (CIDR-G or eCG) nor their interaction had any effect $(P>0.05)$ on percentage of goats expressing estrus. Twenty-four hours before the $\mathrm{PGF}_{2 \alpha}$ injection, two goats, one from GPE and another from GP groups, showed homosexual activity and mucus vaginal discharge indicating estrus expression. Intervals from $0 \mathrm{~h}$ to detected estrus were significantly influenced by eCG $(P<$ 0.03 ) but not by CIDR-G or the interaction between CIDR-G and eCG. Intervals were shorter $(P<0.05)$ in CGPE and GPE groups than in GP with no difference $(P>0.1)$ between CGPE, CGP and GPE or between CGP and GP groups. However, more than $80 \%$ of the goats were bred between 18 and $42 \mathrm{~h}$ of buck introduction. The range of estrus occurrence was from 18-42, 24-54, 18-48 and 36-54 h for CGPE, CGP, GPE and GP, respectively.

Pregnancy was determined based upon progesterone concentrations on day 23 and confirmed on day 35 using ultrasonography. In pregnant goats, progesterone concentrations increased gradually after day 5 and remained elevated through day 23 (Fig. 2). In non-pregnant goats, progesterone concentrations increased after day 5 and then dropped after day 17. Pregnancy and kidding rates were influenced by CIDR-G $(P<0.03)$ but not by eCG or the interaction between CIDR-G and eCG. The proportion of goats that became pregnant and kidding was greater $(P<0.05)$ in CGPE than in GPE and GP with no differences between CGPE and CGP or between GPE and GP (Tab. I). The number of kids born per goat exposed was greater $(P<0.05)$ in CGPE than GPE and GP with no differences $(P>0.1)$ between CGPE and CGP or between CGP, GPE and GP groups. Using the GnRH-PGF $2 \alpha$ protocol, goats pretreated 
Table I. Reproductive performance of GnRH-PGF $2 \alpha^{-}$-treated anestrous goats primed with $300 \mathrm{mg}$ progesterone inserts and eCG at the $\mathrm{PGF}_{2 \alpha}$ injection (CGPE), with $0 \mathrm{mg}$ progesterone (CGP), eCG at the $\mathrm{PGF}_{2 \alpha}$ injection (GPE) or neither progesterone nor eCG (GP).

\begin{tabular}{lcccc}
\hline & \multicolumn{4}{c}{ Treatment* } \\
\cline { 2 - 5 } & CGPE & CGP & GPE & GP \\
\hline No. of goats exposed & 9 & 9 & 9 & 9 \\
No. of goats expressing estrus $(\%)^{1}$ & $9 / 9^{\mathrm{a}}$ & $7 / 9^{\mathrm{a}}$ & $7 / 9^{\mathrm{a}}$ & $6 / 9^{\mathrm{a}}$ \\
Intervals to detected estrus $^{2}$ & $31.3 \pm 3.1^{\mathrm{a}}$ & $36.9 \pm 3.6^{\mathrm{ac}}$ & $32.6 \pm 3.6^{\mathrm{a}}$ & $44.0 \pm 3.8^{\mathrm{bc}}$ \\
No. of goats pregnant $^{3}(\%)$ & $9 / 9^{\mathrm{ae}}$ & $7 / 9^{\mathrm{ce}}$ & $4 / 9^{\mathrm{bc}}$ & $4 / 9^{\mathrm{bc}}$ \\
No. of goats kidding $^{4}(\%)$ & $8 / 9^{\mathrm{ae}}$ & $7 / 9^{\mathrm{ce}}$ & $4 / 9^{\mathrm{bc}}$ & $4 / 9^{\mathrm{bc}}$ \\
Gestation length $($ days $)$ & $147.7 \pm 0.5^{\mathrm{a}}$ & $148.4 \pm 0.6^{\mathrm{a}}$ & $148.3 \pm 0.8^{\mathrm{a}}$ & $149.5 \pm 0.8^{\mathrm{a}}$ \\
Fecundity & $1.9 \pm 0.3^{\mathrm{ad}}$ & $1.0 \pm 0.3^{\mathrm{abc}}$ & $0.7 \pm 0.3^{\mathrm{ce}}$ & $0.6 \pm 0.3^{\mathrm{ce}}$ \\
Prolificacy $^{6}$ & $2.1 \pm 0.2^{\mathrm{a}}$ & $1.3 \pm 0.2^{\mathrm{b}}$ & $1.5 \pm 0.3^{\mathrm{b}}$ & $1.3 \pm 0.3^{\mathrm{b}}$ \\
Multiple birth rates $(\%)$ & $7 / 8^{\mathrm{a}}$ & $2 / 7^{\mathrm{b}}$ & $2 / 4^{\mathrm{b}}$ & $1 / 4^{\mathrm{b}}$ \\
\hline
\end{tabular}

* CGPE $=\left(\right.$ CIDR-G + GnRH + PGF $\left._{2 \alpha}+\mathrm{eCG}\right), \mathrm{CGP}=\left(\mathrm{CIDR}-\mathrm{G}+\mathrm{GnRH}+\mathrm{PGF}_{2 \alpha}\right), \mathrm{GPE}=(\mathrm{GnRH}+$ $\left.\mathrm{PGF}_{2 \alpha}+\mathrm{eCG}\right)$ and $\mathrm{GP}=\left(\mathrm{GnRH}+\mathrm{PGF}_{2 \alpha}\right)$.

a,b,c,d,e Numbers or values within row with similar superscripts are similar $(P>0.1)$.

a,b Numbers or values within row with different superscripts are different $(P<0.05)$.

d,e Numbers or values within row with different superscripts are different $(P<0.01)$

${ }^{1}$ Goats marked by bucks within $72 \mathrm{~h}$ following the $\mathrm{PGF}_{2 \alpha}$ injection.

2 Hours from the time of $\mathrm{PGF}_{2 \alpha}$ injection to the first observation of the breeding mark.

3 Occurring based upon progesterone profiles on day 23 and ultrasonography on day 35 .

${ }^{4}$ Goats kidding from mating at first-cycle service.

5 Number of kids born live per goat exposed.

${ }^{6}$ Number of kids born live per goat kidding.

with progesterone and having received 300 IU eCG injections concomitant with $\mathrm{PGF}_{2 \alpha}(\mathrm{CGPE})$ produced greater $(P<0.05)$ twinning percentages than the goats pretreated with progesterone alone (CGP) or eCG alone (GPE) or neither (GP).

Data were retrospectively grouped, based upon progesterone concentrations on day 0 , to compare parameters in goats with basal or elevated progesterone (ovulation or luteinization) levels on day 0 . Progesterone concentrations were higher $(P<0.01)$ in goats that exhibited estrus $(1.3 \pm 0.1$ vs. $\left.0.5 \pm 0.2 \mathrm{ng} \cdot \mathrm{mL}^{-1}\right)$, became pregnant $(1.4 \pm$ 0.1 vs. $\left.0.5 \pm 0.2 \mathrm{ng} \cdot \mathrm{mL}^{-1}\right)$, kidding $(1.4 \pm$ 0.1 vs. $\left.0.6 \pm 0.2 \mathrm{ng} \cdot \mathrm{mL}^{-1}\right)$ and tended to be different $(P=0.08)$ in goats with multiple births $\left(1.5 \pm 0.2\right.$ vs. $\left.1.1 \pm 0.2 \mathrm{ng} \cdot \mathrm{mL}^{-1}\right)$ than those that did not. Within group, progesterone concentrations in goats that became pregnant and kidding were higher only in the GP group $(P<0.005)$ than goats that did not. All other parameters, within group, were found not to be different. Interestingly, all pregnant goats had elevated progesterone concentration on day 0 and none of the goats with basal progesterone levels became pregnant.

\section{DISCUSSION}

The results of the present study demonstrate that a 5-day progesterone priming prior to a GnRH-PGF $2 \alpha$ treatment combined with eCG at the time of $\mathrm{PGF}_{2 \alpha}$ injection was capable of producing higher rates of pregnancy and kidding. Such a treatment also caused a significant increase in the number of kids born, largely by increasing 

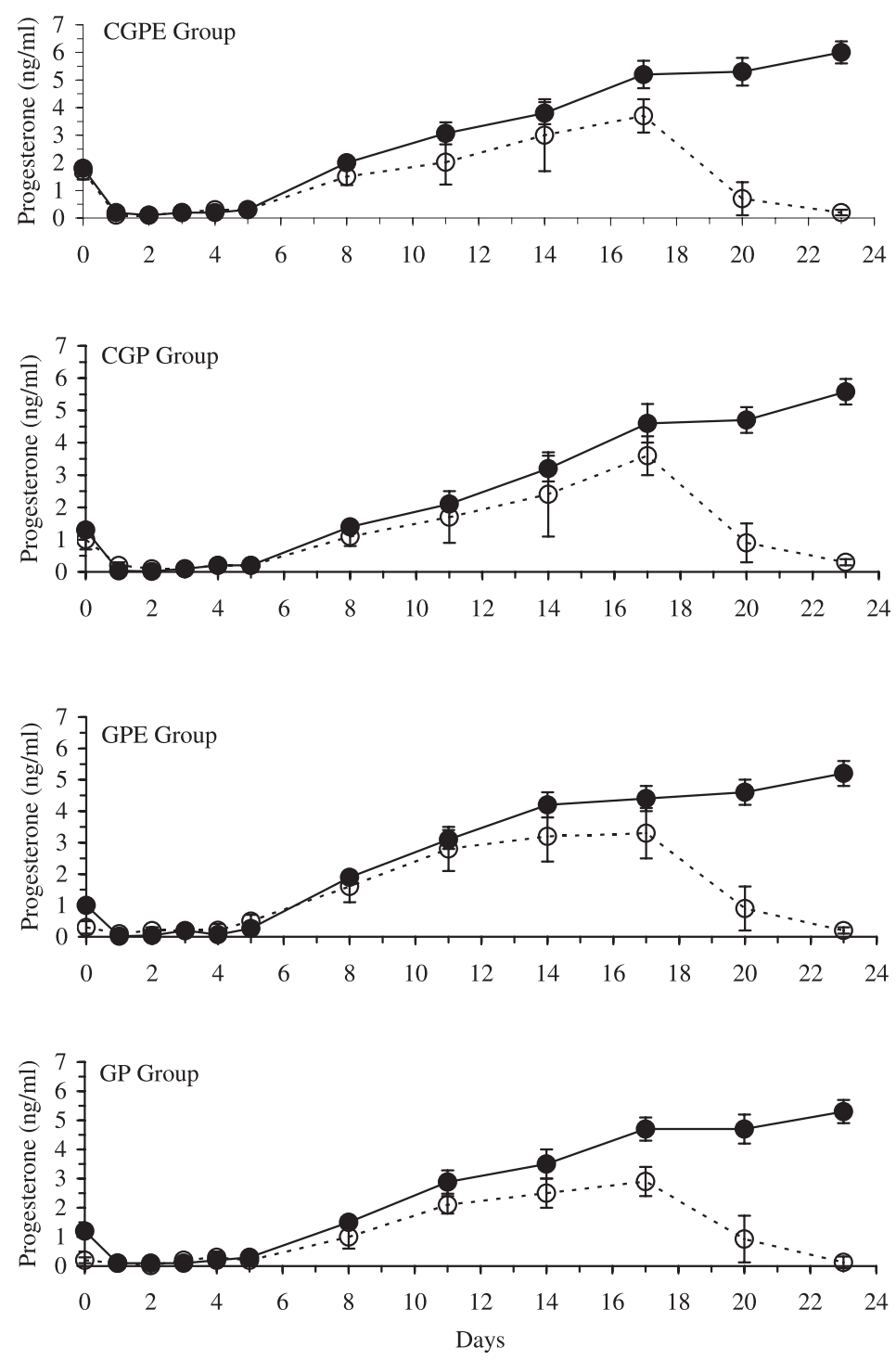

Figure 2. Plasma progesterone profiles following the $\mathrm{PGF}_{2 \alpha}$ injection in GnRH-PGF ${ }_{2 \alpha}$-treated anestrous goats. In pregnant $(\bullet)$ ewes, progesterone concentrations increased and remained elevated through day 23. In non-pregnant $(O)$ ewes, progesterone concentrations increased and then dropped after day 17.

the number of twins in CGPE group. The data obtained from this study indicate that $\mathrm{GnRH}$ based protocols failed to induce fertile cycles in $55.6 \%$ (GPE and GP groups) of the goats, thus, progesterone pretreat- ment was essential for the efficiency of the GnRH-PGF $2 \alpha$ treatment in goats treated out-of-season. This assessment was qualified considerably by the excellent rates of estrus expression (100\%), pregnancy 
(100\%) and kidding (88.9\%) in the CGPE group. It is also noteworthy that there was a higher prolificacy rate among the goats of group CGPE compared to the three other groups. Such a successful outcome is primarily attributed to progesterone priming, illustrating its importance in out-of-season breeding programs.

It is generally accepted that progestageneCG treatment is necessary for out-of-season breeding in small ruminants. However, marginally acceptable fertility rates are usually accompanied such synchronization protocols [12]. Kidding rates between 52 and $66 \%$ have been reported out-of-season using CIDR-G and eCG [12]. During the breeding season, the use of CIDR-G has been reported to produce a kidding rate of $61 \%$ with [13] and $63 \%$ without eCG [14]. Results of CGPE group in the present study showed improvement in kidding rates (88.9\%) compared with those mentioned above. Under Jordanian condition, prolificacy rate averages a little more than $1 \mathrm{kid} /$ doe bred naturally and $1.5 \mathrm{kid} /$ doe treated with progestagen-eCG. The CGPE protocol implemented in the present study has the potential to improve such low reproductive performance. Regarding cost, in Jordan, the CGPE protocol sell for about twice the price of progestagen-eCG. The additional expenses incurred in the present study can be justified by the benefits and return of kidding $(88.9 \%)$ and prolificacy rate $(2.1 \mathrm{kid} / \mathrm{doe})$. This would bring a return of about 4-6 times the expenses spent for implementing such a protocol.

In the present study, the GnRH-PGF $2 \alpha$ protocol alone or with eCG produced low reproductive performance and failed to produce fertile cycles but was successful when goats were primed with progesterone. Progesterone priming prior to $\mathrm{GnRH}$ treatment has been shown to ensure normal luteal function in seasonally anestrous ewes [15, 16]. The abrupt rise in progesterone, following CIDR-G insertion, among goats of groups CGPE and CGP may have caused follicular atresia and emergence of a new follicular wave, which has been demonstrated in cattle [17]. Therefore, progesterone-pretreated goats are expected to have a medium to large size follicle and thus, would have been in mid to late stages of follicular growth at the time when GnRH was injected [18]. The effect of exogenous GnRH varies depending on the stage of the estrous cycle at which GnRH is administered $[19,20]$. Presumably, the GnRH injection induces the preovulatory LH surge, which induces ovulation approximately 24-30 $\mathrm{h}$ following its administration [21] or atresia [22]. Moreover, it is expected that following the GnRH injection, the majority of goats will have similar reproductive patterns and thus, developing corpora lutea, perhaps sensitive enough to be influenced by the $\mathrm{PGF}_{2 \alpha}$ injection. Assuming that progesterone pretreatment mimicked normal luteal function in the CGPE and CGP groups, progesterone concentrations fell to basal values following CIDR-G removal and matched those of groups GPE and GP. Therefore, the GnRH injections were given when all goats had minimal progesterone concentrations. When the $\mathrm{PGF}_{2 \alpha}$ injection is given 6 days following $\mathrm{GnRH}$, it regresses the newly formed corpus luteum from GnRH-induced ovulation, allowing the growth of a new follicular wave, with ovulation occurring 2-3 days later. These findings have been observed in dairy cows treated with GnRH-PGF $2 \alpha$ [8].

Based upon progesterone concentrations, the number of goats ovulating in response to $\mathrm{GnRH}$ injection was significantly increased in CIDR-G treated (CGPE and CGP) groups. As indicated by progesterone concentrations on day 0 , all (100\%) goats in CGPE and CGP groups had progesterone levels $>1.5 \mathrm{ng} \cdot \mathrm{mL}^{-1}$ and all have responded to the $\mathrm{PGF}_{2 \alpha}$ injections. The increase in progesterone is related to the new corpora lutea formed following the GnRH-induced ovulation. The corpus luteum that forms after GnRH administration is capable of undergoing $\mathrm{PGF}_{2 \alpha}$-induced luteolysis following 5 days in goats [23] and sheep [24, 25]. Whereas, $33.3 \%$ and $44.4 \%$ of the 
goats in groups GPE and GP, respectively, had basal progesterone levels on day 0 due to ovulation failure following the $\mathrm{GnRH}$ treatment and therefore, did not respond to the $\mathrm{PGF}_{2 \alpha}$ injection. Among goats with elevated progesterone levels on day $0,8 / 9$ CGPE, 7/9 CGP, 4/9 GPE and 4/9 GP goats became pregnant, reflecting the importance of elevated progesterone on this day. Progesterone priming had significantly elevated progesterone concentrations on day 0 , which further improved the reproductive responses. Such a finding has previously been demonstrated in estrus-synchronized cattle [26]. Therefore, the increased number of goats with elevated progesterone concentrations on day 0 , as observed in CGPE and CGP groups, was of significant value to the results of this study.

Among the groups, no differences were found in the percentages of goats expressing estrus. Progesterone pretreated goats and/or those that had eCG at the time of the $\mathrm{PGF}_{2 \alpha}$ injection exhibited estrus approximately $13 \mathrm{~h}$ earlier than non-progesterone goat that had not received eCG. Estrus distribution among groups occurred between 18 and $54 \mathrm{~h}$ following the $\mathrm{PGF}_{2 \alpha}$ injection, suggesting that the protocol adopted in this study is compact and effective in inducing estrus and producing higher rates of pregnancy and kidding. Although, progesterone priming for 5 days was efficient in inducing estrus in $\mathrm{GnRH}-\mathrm{PGF}_{2} \alpha^{- \text {treated anestrous }}$ goats, the influence of eCG should also be emphasized. Riter et al. [1] reported that eCG action on the ovaries stimulates follicular growth in cyclic or non-cyclic goats and enhances the rate of estrus expression. In agreement with the results of the present study, incorporation of eCG in estrus synchronization protocols reduces the interval from device removal to onset of estrus [27].

The seven goats that did not exhibit estrus within the $72 \mathrm{~h}$ following the $\mathrm{PGF}_{2} \alpha$ injection were 2, 2 and 3 goats from CGP, GPE and GP groups, respectively. The absence of estrus may be due to inadequate estradiol secretion by the ovarian follicles, indicating incomplete follicular growth and development [28, 29]. For unknown reasons, one goat from GPE and another from GP expressed estrus $24 \mathrm{~h}$ before the $\mathrm{PGF}_{2 \alpha}$ injection. It maybe that $\mathrm{GnRH}$ treatment caused follicular atresia in those two goats and therefore, reset the follicular wave [7]. Emergence of a new follicular wave after $\mathrm{GnRH}$ injection may have led to development of a large follicle capable of producing sufficient estradiol that caused estrus signs $[7,30]$. These two goats failed to ovulate in response to the GnRH injection given on day -6 and therefore, they are unlikely they respond to $\mathrm{PGF}_{2 \alpha}$. Such an incident has been observed in dairy cattle treated with GnRH-PGF $2 \alpha[31]$.

Results of the present study are in agreement with a previous study conducted under similar conditions in which GnRH$\mathrm{PGF}_{2 \alpha}$-treated anestrous ewes were pretreated with progesterone for 4 days [11]. According to Billings and Katz [32], progesterone treatment for as little as 3 days facilitated estrogen-induced receptivity and attractivity of goats during the spring and fall. Corteel et al. [13] observed an improved conception rate in anestrous goats treated with CIDR-G and a combination of $\mathrm{PGF}_{2 \alpha}$ and eCG. Overall, the results indicate that the use of the GnRH-PGF $2 \alpha$ protocol without progesterone pretreatment in anestrus goats had no benefits in improving pregnancy and kidding rates or the number of kids born. In conclusion, the success of a GnRH-PGF $2 \alpha$-based program in anestrous goats is dependent on progesterone priming, which along with eCG are essential and offer the opportunity for producing higher rates of pregnancy and kidding. The actions of both progesterone and eCG reside, perhaps, in enhancing follicular growth and development.

\section{ACKNOWLEDGMENTS}

We are grateful to Dr. Ali Dabiri and Dr. Nabeel Salameh (Pharmacia and Upjohn) for providing CIDR-G. The authors express their 
appreciation to H.A. Ghozlan and the staff led by I.M. Tahat for technical assistance and animal management and care at the sheep unit at the Center of Agricultural Research and Production at the Jordan University of Science and Technology.

\section{REFERENCES}

[1] Murdoch WJ, Van-Kirk EA. Luteal dysfunction in ewes induced to ovulate early in the follicular phase. Endocrinology 1998, 139: 3480-3484.

[2] Baril G, Remy B, Leboeuf B, Beckers JF, Saumande J. Synchronization of estrus in goats: the relationship between eCG binding in plasma, time of occurrence of estrus and fertility following artificial insemination. Theriogenology 1996, 45: 1553-1559.

[3] Baird DT, McNeilly AS. Gonadotrophin control of follicular development and function during the estrous cycle of the ewe. J Reprod Fertil Suppl 1981, 30: 119-133.

[4] Thatcher WW, Macmillan KL, Hansen PJ, Drost M. Concepts for regulation of corpus luteum function by the conceptus and ovarian follicles to improve fertility. Theriogenology 1989, 31: 149-164.

[5] Rosenberg M, Kaiw M, Herz Z, Folman Y. Comparison of methods for the synchronization of estrous cycles in dairy cows. 1. Effects on plasma progesterone and manifestation of estrus. J Dairy Sci 1990, 73: 2807-2816.

[6] Wolfenson D, Thatcher WW, Savio JD, Badinga L, Lucy MC. The effect of a GnRH analogue on the dynamics of follicular development and synchronization of estrus in lactating cyclic dairy cows. Theriogenology 1994, 42: 633-644.

[7] Quirke JF, Hanrahan JP, Gosling JP. Duration of estrus, ovulation rate, time of ovulation and plasma LH, total estrogen and progesterone in Galway adult ewes and ewe lambs. J Reprod Fertil 1981, 61: 265-272.

[8] Riter AJ, Maxwell WM, Salamon S. Ovulation and LH secretion in the goat after intravaginal progestagen sponge-PMSG treatment. J Reprod Fertil 1984, 72: 559-563.

[9] Husein MQ, Bailey MT, Ababneh MM, Romano JE, Crabo BG, Wheaton JE. Transcervical artificial insemination of ewes outof-season using frozen-thawed semen: effect of equine chorionic gonadotropin on pregnancy rate. Theriogenology 1998, 49: 9971005 .
[10] Webb R, Baxter G, McBride D, Ritchie M, Sproinbett AJ. Mechanisms controlling ovulation rate in ewes in relation to seasonal anestrus. J Reprod Fertil 1992, 94: 229-241.

[11] Thatcher WW, Drost M, Savio JD, Macmillan KL, Entwistle KW, Schmitt EJ, de la Sota RL, Morris GR. New clinical uses of GnRH and its analogue in cattle. Anim Reprod Sci 1993, 33: 27-49.

[12] Rubianes E, Menchaca A. The pattern and manipulation of ovarian follicular growth in goats. Anim Reprod Sci 2003, 78: 271-287.

[13] Greyling JPC, Van Nierkerk CH, Grobbelaar JAN. Synchronization of estrus in the Boar goat doe: the response to the use of intravaginal progestagen and PMSG. S Afr J Anim Sci 1985, 15: 52-55.

[14] McLeod BJ, Haresign W, Lamming GE. Response of seasonally anestrous ewes to small-dose multiple injections of GnRH with and without progesterone pretreatment. J Reprod Fertil 1982, 65: 223-230.

[15] Moore NM, Eppleston J. The control of estrus, ovulation and fertility in relation to artificial insemination in the angora goat. Aust J Agric Res 1979, 30: 965-972.

[16] Beck NFG, Jones M, Davies B, Peters AR, Williams SP. Estrus synchronization in ewes: The effect of combining a prostaglandin analogue with a GnRH agonist (buserelin). Anim Sci 1996, 62: 85-87.

[17] Riter AJ, Salamon S, Ball PD, O'May PJ. Ovulation and fertility in goats after intravaginal device-PMSG treatment. Small Rum Res 1989, 2: 323-331.

[18] Pierson JT, Baldassare H, Keefer CL, Downey BR. Influence of GnRH administration on timing of the $\mathrm{LH}$ and ovulation in dwarf goats. Theriogenology 2003, 60: 397406.

[19] Twagiramungu H, Guilbault LA, Dufour JJ. Synchronization of ovarian follicular waves with a gonadotropin-releasing hormone agonist to increase the precision of estrus in cattle: A review. J Anim Sci 1995, 73: 3141-3151.

[20] Anderson LH, Day ML. Acute progesterone administration regresses persistent dominant follicles and improves fertility of cattle in which estrus was synchronized with melenogestrol acetate. J Anim Sci 1994, 72: 29552961.

[21] Baril G, Leboeuf B, Saumande J. Synchronization of estrus in goats: the relation between time of occurrence of estrus and fertility following artificial insemination. Theriogenology 1993, 40: 621-628. 
[22] Billings HJ, Katz LS. Facilitation of sexual behavior in French-Alpine goats treated with intravaginal progesterone-releasing devices and estradiol during the breeding and nonbreeding seasons. J Anim Sci 1999, 77: 2073 2078

[23] McLeod BJ, Haresign W. Evidence that progesterone may influence subsequent luteal function in the ewe by modulating preovulatory follicle development. J Reprod Fertil 1984, 71: 381-386.

[24] Seguin B. Estrus synchronization. In: Current Veterinary Therapy, Howard and Smith (Eds), W.B. Sounders Co, Philadelphia, 1999, p 580-587.

[25] Waldron DF, Willingham TD, Thompson PV, Bretzlaff KN. Effect of concomitant injection of prostaglandin and PMSG on pregnancy rate and prolificacy of artificially inseminated Spanish goats synchronized with controlled internal drug release devices. Small Rumin Res 1999, 31: 177-179.

[26] Romano JE. Synchronization of estrus using CIDR, FGA or MAP intravaginal pessaries during the breeding season in Nubian goats. Small Rumin Res 2004, 55: 15-19.

[27] Corteel JM, Leboeuf B, Baril G. Artificial breeding of adult goat and kids induced with hormones to ovulate outside the breeding season. Small Rumin Res 1988, 1: 19-35.

[28] Dahms MK, Barthle C, Portillo GE, Thatcher W, Yelich JV. Duration of melenogestrol acetate treatment in a GnRH or estradiol benzoate/progesterone and prostaglandin F2alpha synchronization system in cattle of Bos indicus breeding. UF-IFAS. Beef Report-Dep Anim Sci 2002, p 69-71.

[29] Cardenas H, McClure KE, Pope WF. Luteal function and blastocyst development in ewes following treatment with $\mathrm{PGF}_{2 \alpha}$ and $\mathrm{GnRH}$. Theriogenology 1993, 40: 865-872.

[30] Husein MQ, Kridli RT. Effect of progesterone prior to $\mathrm{GnRH}-\mathrm{PGF}_{2 \alpha}$ treatment on induction of estrus and pregnancy in anestrous Awassi ewes. Reprod Domest Anim 2003, 38: 228232.

[31] Robin N, Laforest JP, Lussier JG, Guilbault LA. Induction of estrus with intramuscular injections of GnRH or PMSG in lactating goats (Capra hircus) primed with progestagen during seasonal anestrus. Theriogenology 1994, 42: 107-116.

[32] Cartmill JA, El-Zarkouny SZ, Hensley BA, Lamb GC, Stevenson JS. Stage of cycle, incidence, and timing of ovulation, and pregnancy rates in dairy cattle after three timed breeding protocols. J Dairy Sci 2003, 81: 1051-1059. 